\title{
The Diffusion of Policy Innovations: Determinants of the Administrative Information Disclosure Acts among Local Governments in Korea
}

\author{
Sexng Jong Lee* and Ji Kyoung Yum**
}

\begin{abstract}
What determines the diffusion of policy innovations among localities? In order to answer this question, this study tested empirically competing models of the diffusion of local policy innovations by analyzing the diffusion process of the local information disclosure acts among Korean local governments. In doing so, two existing models-the geographic proximity model and the internal attributes model-and a newly proposed model here-the vertical influence model-are analyzed. Specifically, employing factors reflecting the presumptions of each model, regression analyses were performed on two dependent variables: the adoption and the adoption speed of local policy innovations. For the adoption, both the internal attributes model and the vertical influence model were supported. But the geographic proximity model was not supported. For the adoption speed, again the two models were supported, but the geographic proximity model failed to find support again, which necessitates a more rigorous analysis, as the model has widely gathered supportive evidences. The newly proposed theoretical model was consistently supported in our analyses, which signifies that the diffusion of local innovations is not insulated from the influences of upper authorities.
\end{abstract}

Keywords: policy diffusion, policy innovation, local policy, information act

* Seung Jong Lee ( $\mathrm{PhD}$, Northwestern University) is a Professor in the Graduate School of Public Administration at Seoul National University, and editor-in-chief of the Korean Public Administration Review. E-mail: slee@snu.ac.kr

** Ji Kyoung Yun is a Graduate Student of the Graduate School in Public Administration at Seoul National University. His research interests include local politics and civic participation. E-mail: ilysyjk0@snu.ac.kr

Manuscript received December 2006; out for review December 2006; review completed January 2007; accepted February 2007.

The Korean Journal of Policy Studies, Vol. 21, No. 2, $41-56$ (2007)

(C) 2007 by the GSPA, Seoul National University 


\section{PURPOSE}

Policy innovations implemented by the central government are transmitted as mandates and applied uniformly across local governments regardless of the intentions or specific conditions of each local government, whereas policy innovations produced by local governments follow a natural diffusion process. Local governments can choose whether to adopt new policies of other local governments depending on their own will, capacity, or external conditions.

Although policy diffusion among local innovations is not so fast or integrated as policy transmission from the central government to local governments, it has an advantage in ensuring local autonomy as well as policy diffusion. In addition, local policy diffusion mechanisms have a more important advantage: They automatically facilitate the diffusion of good policies and interrupt the diffusion of undesirable ones, which is realizable by the independent choices of each local government without central interventions. This automatic nature of policy diffusion mechanism among local governments is an important theoretical basis supporting local autonomy. ${ }^{1}$

What determines the diffusion of policies among localities? This paper purports to answer the question based on an analysis of the diffusion process of the administrative information disclosure acts (referred to here as the information acts) in local governments. Specifically, it examines the effects of various factors such as socioeconomic conditions, geographic proximity, and regional government behaviors on the adoption and adoption speed of the information acts among Korean local governments during 1992-1998. 2 The reason for employing such a time scope is that the diffusion of the information acts began after the inception of the act by Cheong ju City in 1992 and nearly stopped after the enactment of the central information act in 1998, which is effective at both the local and state levels.

\section{THEORETICAL MODELS}

Policy diffusion has been one of the most attractive topics for many researchers. Since the pioneering work of Walker (1969), which identified factors that stimulate and shape policy diffusion, a lot of research has attempted to explain how policy inno-

1. Here, policy innovation, following Walker (1969), is defined simply as a policy that is new to local governments.

2. Korean local governments include those at the regional level and the city-county level. In this paper, the term 'local governments' indicates city-county local governments. 
vations spread to other local or state governments (e.g., Baum, 1981; Berry \& Berry, 1990; Boehmke \& Witmer, 2004; Clark, 1985; Gray, 1973a; Hays, 1996; Mintrom, 1997; Mintrom \& Vergari, 1998; Shannon \& Bashshur, \& Metzner, 1971). Although the research foci and analytical results of the previous studies are diverse, generally speaking, two explanatory models have competed in the previous studies-the geographic proximity model and the internal attributes model. Together, these two models help us to understand horizontal policy diffusion mechanisms among local governments, but they are limited in that they fail to take into consideration the impact of intergovernmental relations on the diffusion of local policy. In this regard, we attempt to build another explanatory model here-a vertical influence model.

\section{The Geowraphic Proximity Model}

The geographic proximity model posits that local policy diffusion occurs when local governments copy the new policies of adjacent local governments (e.g., Berry, 1994; Light, 1978; Sharkansky, 1970; Walker, 1969, 1973). That process occurs, according to Walker (1969), because local policymakers seek to find policies to import from adjacent localities in order to simplify their decision-making costs. In that process, the scope of policy diffusion tends to be limited within the region to which a local government belongs rather than nationally because there exists a spatial barrier. According to research supporting this thesis, this applies not only to local governments (Walker, 1973) but also to regional governments (Light, 1978; Sharkansky, 1970). Not all researchers agree on this. For example, Gray (1973a) argues that the influence of adjacent localities differs depending on policy issues, and the federal govemment can affect local governments strongly - thus the diffusion of local policies may transcend local or regional barriers and spread at the national level. With this exception, however, most of studies in this line have highlighted the influence of adjacent localities rather than the national level diffusion of policies. Also, this model focuses on diffusion patterns rather than the factors influencing policy diffusion among localities, to which the internal model pays special attentions.

\section{The Internal Attributes Model}

The internal attributes model complements the geographic proximity model by considering endogenous factors in addition to geography. More specifically, this model posits that the diffusion of local policy innovations depends on the political, social, and economic factors of local governments and attempts to identify factors that determine the decisions of local governments to adopt local policy innovations (Canon 
\& Baum, 1981; Gray, 1973a; Park, 1983; Rogers, 1983). Such factors include political competition, fiscal capacity (Gray, 1973a, 1973b), the size of local councils, voter turnout, population size, the educational achievement of local residents, and the type of local government (Namkung, 1994). By relating such factors with one or more policies, researchers have attempted to verify the influence of internal attributes on the diffusion of policies. For example, Gray (1973a) examined policy diffusion patterns in civil rights, welfare, and education and reported that internal attributes affect policy diffusion among local governments.

\section{A Vertical Influence Model}

Although we classify the explanatory models of policy diffusion into two categories, they are not necessarily incompatible because the policy diffusion of local innovations can be determined by both proximity and internal attributes. In this recognition, some have attempted to integrate the explanations of the two models of policy diffusion. For example, Berry and Berry (1990) tried to show the compatibility of two explanatory models of innovation by relying on Mohr's (1969) theory of organizational innovation, which suggests that internal attributes and geographic proximity are important factors in organizational innovation. Specifically, they put the two models of policy diffusion to an empirical test by analyzing the policy case of state lottery adoption and found that the two models are valid. Namkung (1994) also tried to explain the adoption process of the information acts in localities by combining the geographic proximity model and the internal attributes model. In his analysis, independent variables such as earlier adjacent adopter, the size of local councils, and voter turnout were significant predictors of the adoption of information acts and proved both the geographic proximity model and the internal attributes model.

Aside from the compatibility of the two models, as indicated before, the explanations provided by the two models are limited because they fail to adequately explicate the effect of intergovernmental relations on policy diffusion among local governments. Nonetheless, existing studies, by focusing on the relative advantages of the characteristics of local governments, have neglected to examine the influences of upper level governments - both national and regional - on local initiatives. It should be noted, however, that such influences could be deterministic, especially in countries where a tradition of vertical control in intergovernmental relations has prevailed over a long period of time, as in Korea.

Based on this acknowledgement, we propose here a new explanatory model that posits the diffusion of local policy innovations among local governments is a function of the vertical influences of upper level governments, as well as the horizontal influ- 
ences of other local governments - the main rationales of the two previous explanatory models. Even before a serious test, this new model gets initial support from the aforementioned observation that the adoption of the information acts in Korean local governments nearly stopped immediately after the enactment of the central information act in 1998 .

\section{ANALWSIS}

In order to test the relative validity among these models, this study analyzed the diffusion of the information acts among 230 Korean local governments employing a cross-sectional analysis. The diffusion of the information acts among local governments of Korea is a relevant local policy case to test the models of policy diffusion among localities, as the first local information act of Cheong Ju City, enacted after a year-long struggle against the central government's intention to thwart it, was initiated by purely voluntary local efforts and its diffusion among local governments preceded the enactment of the national information disclosure law. That is, the policy case can be characterized exactly as a case of the diffusion of local policy innovations. Also, the policy is new in Korea, where no acts had been enacted for opening administrative information to citizens before that of Cheong Ju City. In short, the diffusion of the information acts among Korean local governments is a good example of local and innovative policies. For reference, detailed information on the adoption of the information acts by Korean local and regional governments is presented in Appendix.

It seems that there are two distinct aspects of the diffusion of local policy innovations - the adoption of the innovated policy and the speed of its adoption. Reflecting this, we employed two dependent variables: the adoption of the information acts and the adoption speed. The former is a dummy variable with a value of 1 for the adopted local govermment and 0 for the unadopted. The latter variable indicates the year in which a local government adopted the act. The values for the variable were coded 7 to 1 in order, with the faster localities receiving higher scores. For instance, local governments that adopted the acts in 1992 were the fastest and received a score of 7 , whereas local governments that adopted in 1998 were the last ones and received a score of 1.

The independent variables were chosen to reflect the explanatory models presented earlier. For the internal attributes model, these variables are the fiscal capacity of the local government, the mayor's political party affiliations, whether the local government was operating under local elections or central appointments, voter turnout for the 1995 local election, local council size, and the type of local government (county/ urban). For the geographic proximity model, the variable is the adoption ratio of adja- 
cent local government. And for the vertical influence model, the variable is the adoption of the information acts by the regional government.

Basically, specific data years for the independent variables were selected from the data one year before $(t-1)$ the year in which the acts were adopted $(t)$, presuming at least a year's gap between the independent and dependent variables. This basic principle does not apply to the unadopted local governments because we could not designate a specific year as the adoption year. Accordingly, for the unadopted local governments, data for the independent variables are uniformly from 1997, one year prior to the last year of policy adoption analyzed in this study. For the dummy variable, X3 (local governments elected or not), there is no difference between the adopted and unadopted local governments. All local governments were under the central-appointment system before 1995 and under the electoral system after 1995. Exceptionally, the data for voter turnout (X4) were drawn from the local election in 1995.

Data were extracted from the annual fiscal reports and internal reports of the Korean Ministry of Government and Home Affairs, including the Annual Report of Administrative Districts and Home Affairs, and the Reports of the National Commission for Elections.

A list of dependent and the independent variables is given in Table 1.

Table 1. Dependent and Independent Variables

\begin{tabular}{|c|c|c|c|}
\hline & Variables & Value $^{3}$ & Data year \\
\hline \multirow{2}{*}{$\begin{array}{l}\text { Dependent } \\
\text { variables }\end{array}$} & $\begin{array}{l}\text { Adoption of the } \\
\text { information acts ( } \mathrm{Y} 1)\end{array}$ & $\begin{array}{l}\text { Adopted }=1 \\
\text { Unadopted }=0\end{array}$ & \\
\hline & Speed of adoption (Y2) & $\begin{array}{l}1992=7-1998=1, \\
\text { (in order) }\end{array}$ & \\
\hline \multirow[b]{3}{*}{$\begin{array}{l}\text { Internal } \\
\text { attributes model }\end{array}$} & Fiscal capacity (X1) & Numerical & $\begin{array}{l}\text { Adopted }=t-1 \\
\text { Unadopted }= \\
1997 \text { data }\end{array}$ \\
\hline & $\begin{array}{l}\text { Elected mayor's political } \\
\text { party affiliation }(\mathrm{X} 2)\end{array}$ & $\begin{array}{l}\text { Ruling party }=1, \\
\text { Opposition party }=0\end{array}$ & same as above \\
\hline & $\begin{array}{l}\text { Local governments elected } \\
\text { or not (X3) }\end{array}$ & $\begin{array}{l}\text { Local governments under } \\
\text { electoral system } \\
\text { (after } 6 / 1995 \text { ) }=1 \text {, } \\
\text { Local governments under } \\
\text { appointment system } \\
\text { (before } 6 / 1995 \text { ) }=0\end{array}$ & $\begin{array}{l}\text { No difference } \\
\text { between adopted } \\
\text { /Unadopted }\end{array}$ \\
\hline
\end{tabular}

3. For local governments that adopted the information acts after the city-county consolidation of the mid 1990s, data for independent variables are an average of the data of each local government before the integration. 


\begin{tabular}{l|l|l|l}
\hline & $\begin{array}{l}\text { Voter turnout in local } \\
\text { election }(X 4)\end{array}$ & Percentage & $\begin{array}{l}\text { Local election in } \\
1995\end{array}$ \\
\cline { 2 - 4 } $\begin{array}{l}\text { Internal } \\
\text { attributes model }\end{array}$ & $\begin{array}{l}\text { Size of the local council } \\
(\mathrm{X} 5)\end{array}$ & $\begin{array}{l}\text { Number of councilors per } \\
1,000 \text { residents }\end{array}$ & $\begin{array}{l}\text { Adopted }=t-1, \\
\text { Unadopted }= \\
1997 \text { data }\end{array}$ \\
\cline { 2 - 4 } & County/Urban (X6) & $\begin{array}{l}\text { County=1, } \\
\text { Urban=0 }\end{array}$ & $\begin{array}{l}\text { Adopted }=t-1, \\
\text { Unadopted }= \\
1997 \text { data }\end{array}$ \\
\hline $\begin{array}{l}\text { Geographic } \\
\text { proximity model }\end{array}$ & $\begin{array}{l}\text { Adoption ratio of adjacent } \\
\text { local governments (X7) }\end{array}$ & $\begin{array}{l}\text { Number of adjacent adopted/ } \\
\text { Number of the adjacent }\end{array}$ & $\begin{array}{l}1997 \text { data for } \\
\text { Unadopted }\end{array}$ \\
\hline $\begin{array}{l}\text { Vertical } \\
\text { influence model }\end{array}$ & $\begin{array}{l}\text { Adoption by regional } \\
\text { government (X8) }\end{array}$ & $\begin{array}{l}\text { Adopted }=1, \\
\text { Unadopted }=0\end{array}$ & $\begin{array}{l}1997 \text { data for } \\
\text { Unadopted }\end{array}$ \\
\hline
\end{tabular}

\section{The Adoption of the Innformation Acrs}

Which factors are significant predictors of the adoption of the information acts among local governments? And which model is relevant in explaining the diffusion of local policy innovations? In order to answer to these questions, a logistic regression analysis was performed using 223 local cases, excluding missing cases. A logistic regression analysis was performed because the values for the dependent variable are dichotomous. The logistic regression model used in this analysis takes the following basic form.

Adoption of the local information acts = f(internal attributes, geographic proximity, regional government's behavior)

The results of the analysis are reported in Table 2 . The value of chi-square $(222.885)$ is statically significant $(d f=8, p<.001)$ and indicates that the proposed logit model is adequate.

Among the eight independent variables, only two variables turned out to be significant predictors of the adoption of the information acts-local governments under elected mayors $(\mathrm{X} 2, p<.001)$ and adoption by the regional government $(\mathrm{X} 7, p<$ .001 )-which supports the internal attributes model and the vertical influence model but not the geographic proximity model.

The sign of the coefficient for X2 (local governments under elected mayors) is negative, which signifies that autonomous local governments under elected mayors have a tendency to resist the adoption of policy innovations more than local governments under appointed mayors. It is misleading, however, if we construe this result as evidence that elected mayors are more reluctant to adopt local innovations than appointed 
Table 2. Determinants of the Adoption of the Local Information Acts $(\mathrm{N}=223$ )

\begin{tabular}{|c|c|c|c|c|c|}
\hline & Variable & $\mathrm{B}$ & S.E. & Wald & $p$ value \\
\hline \multirow{6}{*}{$\begin{array}{l}\text { Internal attributes } \\
\text { model }\end{array}$} & Fiscal capacity (X1) & -.010 & .028 & .140 & .708 \\
\hline & Mayoral party (X2) & -.975 & .746 & 1.712 & .191 \\
\hline & Local government elected (X3) & -7.221 & 1.242 & 33.815 & .000 \\
\hline & Voter turnout $(\mathrm{X} 4)$ & .150 & .093 & 2.614 & .106 \\
\hline & Local council size $(X 5)$ & -7.913 & 9.827 & .649 & .421 \\
\hline & County/Urban (X6) & -1.563 & 1.051 & 2.209 & .137 \\
\hline $\begin{array}{l}\text { Geographic } \\
\text { proximity model }\end{array}$ & $\begin{array}{l}\text { Adoption ration of adjacent } \\
\text { local government }(X 7)\end{array}$ & .011 & .011 & .896 & .344 \\
\hline \multirow[t]{2}{*}{$\begin{array}{l}\text { Vertical influence } \\
\text { model }\end{array}$} & $\begin{array}{l}\text { Adoption by regional } \\
\text { government (X8) }\end{array}$ & 3.111 & .898 & 11.991 & .001 \\
\hline & Constant & -4.708 & 6.576 & .513 & .474 \\
\hline \multicolumn{6}{|c|}{$\begin{array}{c}-2 \text { Log likelihood }=66.0354 \\
\text { chi-square }=222.885, d f=8, p=.001 \\
\text { Cox \& Snell's } R^{2}=0.634, \text { Nagelkerke } R^{2}=0.871\end{array}$} \\
\hline
\end{tabular}

mayors, as there are other factors that influence the decisions of local governments to adopt local innovations. Of course, there is a possibility that elected mayors are more interested in political negotiations aimed at winning political supports than adopting policy innovations. But even if that is true, it should be noted that the mayoral factor is not the only factor affecting the adoption of local innovative policies, and thus we cannot conclude that our regression result reveals that elected mayors are reluctant to adopt innovative policies.

Other internal attributes besides the variable X2 (local governments under elected mayors) appeared to be insignificant predictors, which undermines the explanatory power of the internal attributes model to that extent.

\section{The Speed of Adoption}

Which factors are significant predictors of the adoption speed of the information acts among local governments? And which model is relevant in explaining the adoption speed of local policy innovations? In order to answer to these questions, a regression analysis was performed using 76 local governments that adopted the information acts. Unlike the previous analysis, an ordinary least squares analysis was performed because the values for the dependent variable are continuous, and the regression model employed in this analysis takes the same form as before: 
The adoption speed of the local information acts $=f($ internal attributes, geographic proximity, regional government's behavior)

Table 3. Determinants of the Adoption Speed of the Information Acts $(\mathrm{N}=76)$

\begin{tabular}{|c|c|c|c|c|c|c|}
\hline & & \multicolumn{2}{|c|}{$\begin{array}{c}\text { Unstandardized } \\
\text { regression coefficient }\end{array}$} & \multirow{2}{*}{\begin{tabular}{|c|}
$\begin{array}{c}\text { Standardized } \\
\text { regression } \\
\text { coefficient }\end{array}$ \\
$\beta$ \\
\end{tabular}} & \multirow[t]{2}{*}{$t$} & \multirow[t]{2}{*}{$p$ value } \\
\hline & & B & S.E. & & & \\
\hline \multirow{6}{*}{$\begin{array}{l}\text { Internal } \\
\text { attributes model }\end{array}$} & Fiscal capacity (X1) & -.001 & .005 & -.011 & -.154 & .878 \\
\hline & Mayoral party (X2) & .019 & .148 & .006 & .125 & .900 \\
\hline & $\begin{array}{l}\text { Local government } \\
\text { elected (X3) }\end{array}$ & -2.796 & .217 & -.629 & -12.856 & .000 \\
\hline & Voter turnout (X4) & -.051 & .019 & -.243 & -2.710 & .008 \\
\hline & County/Urban (X6) & .886 & .200 & .311 & 4.425 & .000 \\
\hline & Local council size $(X 5)$ & 3.818 & 1.672 & .158 & 2.283 & .024 \\
\hline $\begin{array}{l}\text { Geographic } \\
\text { proximity model }\end{array}$ & $\begin{array}{l}\text { Adoption ratio of } \\
\text { adjacent local } \\
\text { government }(X 7)\end{array}$ & -.013 & .002 & -.295 & -5.383 & .000 \\
\hline \multirow[t]{2}{*}{$\begin{array}{l}\text { Vertical } \\
\text { influence model }\end{array}$} & $\begin{array}{l}\text { Adoption by regional } \\
\text { government (X8) }\end{array}$ & -.420 & .165 & -.133 & -2.544 & .012 \\
\hline & Constant & 8.809 & 1.347 & & 6.541 & \\
\hline \multicolumn{7}{|c|}{$\begin{array}{c}\text { chi-squares }=281.222, d f=143, F=41.129(P<.001) \\
R^{2}=0.709, \text { Adjusted } R^{2}=0.692\end{array}$} \\
\hline
\end{tabular}

The analytical results are presented in Table 3. The $F$ value (41.129) is statistically significant $(p<.001)$ and tells us that the proposed model is appropriate. Also, the high level of the coefficient of determination $\left(R^{2}\right)$ indicate that the predictive power of our regression model employed is high and strengthens the validity of the test.

Compared with the previous analysis, more independent variables turned out to be significant predictors of the adoption speed of the information acts: The local governments under elected mayors $(X 2, p<.001)$, voter furnout $(X 4, p<.01)$, the size of the local council $(\mathrm{X} 5, p<.05)$, county govermment $(\mathrm{X} 6, p<.001)$, the adoption ratio of adjacent local govemments $(X 7, p<.05)$, and adoption by the regional government $(\mathrm{X} 8, p<.05)$. The internal attributes model and the vertical influence model are supported by these results. We will discuss later whether the variable $X 7$ (adoption ratio of adjacent local governments) supports the geographic proximity model.

Among the independent variables reflecting the internal attributes model, local governments under elected mayors (X2) again was negatively associated with the speed of adoption. Voter tumout (X4) had a negative and county governments (X6) a positive 
correlation with the speed of adoption. The former may be explained by opinion conflicts and decision delays embedded in active participative political culture. Similarly, the latter result may reflect a more homogeneous opinion structure in county areas compared with a more heterogeneous opinion structure in urban areas. Together, these results give stronger support to the internal attributes model than the previous analysis.

The variable chosen for the geographic proximity model - the adoption ratio of adjacent local governments (X7) - turned out to be a significant variable in this analysis, unlike the previous analysis. However, it was negatively associated with the speed of adoption. This negates the basic principle of the geographic proximity model, which posits "more proximity, more policy diffusion." How can we explain this counterintuitive result? It may be there is some rivalry among adjacent localities, but we cannot confirm this speculation. In order to answer to this, we need more in-depth observations for a few selected cases. Regardless, this negative result, together with the previous insignificant one, suggests that the explanatory power of the geographic proximity be doubtable.

Regarding the vertical influence model, the variable X8 (adoption by the regional government) again turned out to be positively related with adoption speed and supports the model.

\section{CONCLUSION}

This study empirically tested competing models of the diffusion of policy innovations among local governments by analyzing the diffusion process of the Local Information Disclosure Acts among Korean local governments. With regard to adoption, both the internal attributes model and the vertical influence model proposed were supported by the analysis, although the former was supported only partially. The geographic proximity model was not supported. With regard to adoption speed, again the two models were supported, but the geographic proximity model failed to find support again, which necessitates a more rigorous analysis, as the model has widely gathered supportive evidence.

It is remarkable that the theoretical model proposed here was consistently supported in our analyses, which suggests that the diffusion of local innovations is not insulated from the influence from upper authorities. This corresponds to the indication that it is necessary to take intergovernmental relations into serious consideration when discussing local decision processes. Previous studies of the diffusion of innovative policies have generally neglected this aspect and failed to provide a more comprehensive explanation.

It is notable that elected local governments had negative relationships with both 
adoption and adoption speed (X3). Also, voter turnout (X4) in local elections was a negative predictor of the speed of adoption of the information acts. These results might be construed as evidence revealing democratic inefficiency. That may be true, but a more cautious evaluation is necessary because the negative relationships themselves may manifest the existence of a democratic deliberative process in local policy decisions, which is more than enough to counterbalance the democratic inefficiency.

It is noteworthy that the significant predictors of adoption and adoption speed were not identical, which suggests the need to develop different models explicating differential causal relationships between the independent and dependent variables. For that modeling, it would be helpful to have a better understanding of the relationship between adoption per se and the speed of adoption.

Finally, as we have seen before, the factors affecting adoption and adoption speed were different. This suggests that influencing factors may vary depending on the characteristics of each policy. That is, it seems that policy types matter here, too (Lowi, 1964). Nonetheless, we assumed that influencing factors are uniformly associated with the policy diffusion and applied the same model regardless of policy area. If this speculation is right, we need to develop a newer model to incorporate the element of policy type or specific policy issue and examine its validity with more comprehensive data in the future. In this regard, Gray (1973a) argued that factors affecting policy diffusion are not different across large policy areas and can be differential across specific policy issues or time, at best. Although it is still uncertain whether her argument is valid, it suggests that we need to be more careful in developing a policy-type-matter model of the diffusion of policy innovations. That is, we need to determine at which level policy type or issue matter affects the diffusion in model building effort. By doing so, we may get a more comprehensive and relevant explanation of the diffusion of local policy innovations.

\section{REFERENCES}

Berry, F. S. (1994). Innovation in public management: The adoption of strategic planning. Public Administration Review, 54(4), 322-330.

Berry, F. S., \& Berry, W.D. (1990). State Lottery Adoptions as Policy Innovations: An Event History Analysis. American Political Science Review, 84(2), 395-415.

Boehmke, F., \& Witmer, R. (2004). Disentangling Diffusion: The effects of social learning and economic competition on State Policy Innovation and Expansion. Political Research Quarterly, 57(1), 39-51.

Canon, B. C., \& Baum, L. (1981). Patterns of adoption of tort law innovations: An application of diffusion theory to judicial doctrines. American Political Science 
Review, 75(4), 975-987.

Clark, J. (1985). Policy Diffusion and Program Scope: Research Directions. Publius, 15(4), 61-70.

Gray, V. (1973a). Innovation in the states: A diffusion study. American Political Science Review, 67(4), 1174-1184.

Gray, V. (1973b). Rejoinder to "comment" by Jack L. Walker. American Political Science Review, 67(4), 1192-1193.

Hays, S. P. (1996). Influences on Reinvention during the Diffusion of Innovation. Political Research Quarterly, 49(3), 631-650.

Lee, S. J. (1995). Public officials' evaluation of the effects of the local acts for administrative information disclosure: The case for Cheongju City. Korean Public Administration Review, 29(4), 1275-1289.

Light, A. R. (1978). Intergovernmental sources of innovation in state administration. American Politics Quarterly, 6(2), 147-165.

Lowi, T.J. (1964). American business, public policy, cases studies and political theory. World Politics, 16(4), 677-719.

Korea Ministry of Government Administration and Home Affairs. (1999). Annual report of the information disclosures. Seoul: Authur.

Mintrom, M. (1997). Policy Entrepreneurs and the Diffusion of Innovation. American Journal of Political Science, 41(3), 738-770.

Mintrom, M., \& Vergari, S. (1998). Policy Networks and Innovation Diffusion: The case of State Education Reforms. The Journal of Politics, 60(1), 126-148.

Mohr, L.B. (1969). Determinants of innovations in organizations. Americal Political Science Review, 63(1), 111-126.

Namkung, K. (1994). The adoption of the administrative information disclosure acts of local governments as policy innovations. Korean Political Science Review, 28(1), 1101-1121.

Park, Y. C. (1983). The diffusion process of innovations. Seoul: Koryowon.

Rogers, E. M.(1983). Diffusion of innovations. New York: Free Press.

Sabatier, P., \& Mazmanian, D. (1980) . The implementation of public policy: A framework of analysis. Policy Studies Journal, 8(4), 538-559.

Shanon, G. W., \& Bashshur, R. L., \& Metzner, C. A. (1971). The Spatial Diffusion of an Innovative Health Care Plan. Journal of Health and Social Behavior, 12(3), 216-226.

Sharkansky, I. (1970). Regionalism in American politics. Indianapolis, IN: BobbsMerrill.

Smith, T. A. (1988). Time and public policy. Knoxville. Tennessee: The University of Tennessee Press. 
Walker, J. L. (1969). The diffusion of innovations among the American states. American Political Science Review, 63(3), 880-899.

Walker, J. L. (1973). Comment: Problems in research on the diffusion of policy innovation. American Political Science Review, 67(4), 1186-1191.

\section{APPENDIX}

\begin{tabular}{|c|c|c|}
\hline Regional governments & Local governments & Time of Adoption \\
\hline \multirow{13}{*}{ Seoul metropolitan city } & Seongdong-gu & 1994. 3.24 \\
\hline & Gwangjin-gu & 1995. 3.13 \\
\hline & Dongdaemun-gu & 1998. 4. 1 \\
\hline & Jungnang-gu & 1993.8 .25 \\
\hline & Seongbuk-gu & 1993. 4.3 \\
\hline & Nowon-gu & 1994.11.14 \\
\hline & Yangcheon-gu & 1993. 4.30 \\
\hline & guro-gu & 1994.12.27 \\
\hline & Geumcheon-gu & 1995. 3. 2 \\
\hline & Gwanak-gu & 1994. 3.21 \\
\hline & Seocho-gu & 1994.12 .13 \\
\hline & Gangnam-gu & 1993.11.12 \\
\hline & Gangdong-gu & 1997. 8.11 \\
\hline \multirow{13}{*}{ Busan-si } & Busan-si & 1993.6 .3 \\
\hline & Dong-gu & 1994. 2.21 \\
\hline & Yeongdo-gu & 1993.10 .5 \\
\hline & Busanjin-gu & 1994.7 .1 \\
\hline & Dongnae-gu & 1994. 5.2 \\
\hline & Nam-gu & 1992.10 .10 \\
\hline & Buk-gu & 1995.5 .27 \\
\hline & Haeundae-gu & 1993.1 .11 \\
\hline & Saha-gu & 1996. 4.15 \\
\hline & Yeonje-gu & 1995. 3. 2 \\
\hline & Suyeong-gu & 1997. 9.11 \\
\hline & Sasang-gu & 1995.8 .12 \\
\hline & Gijang-gu & 1995. 3. 2 \\
\hline \multirow{2}{*}{ Incheon-si } & Nam-gu & 1993.1 .11 \\
\hline & Yeonsu-gu & 1995. 4. 1 \\
\hline \multirow{5}{*}{ Gwangju-si } & Gwangju-si & 1993.1 .11 \\
\hline & Dong-gu & 1996.10.11 \\
\hline & Seo-gu & 1992.10 .13 \\
\hline & Nam-gu & 1995.3. 2 \\
\hline & Gwngsan-gu & 1992. 8.7 \\
\hline
\end{tabular}




\begin{tabular}{|c|c|c|}
\hline Regional governments & Local governments & Time of Adoption \\
\hline \multirow{6}{*}{ Ulsan-si } & Ulsan-si & 1997.7 .15 \\
\hline & Jung-gu & 1997.7 .15 \\
\hline & Nam-gu & 1997. 7.15 \\
\hline & Dong-gu & 1997. 7.15 \\
\hline & Buk-gu & 1997. 7.15 \\
\hline & Ulju-gun & 1997.11 .10 \\
\hline \multirow{25}{*}{ Gyeonggi-do } & Gyeonggi-do & 1992.12 .7 \\
\hline & Suwon-si & 1993. 4.12 \\
\hline & Seongnam-si & 1993.8 .5 \\
\hline & Anyang-si & 1992.11 .30 \\
\hline & Bucheon-si & 1994. 5.31 \\
\hline & Gwangmyeong-si & 1993.11 .24 \\
\hline & Pyeongtaek-si & 1995. 5.10 \\
\hline & Dongducheon-si & 1994. 1.12 \\
\hline & Ansan-si & 1994. 9.12 \\
\hline & Goyang-si & 1995.5 .13 \\
\hline & Gwacheon-si & 1993.9 .2 \\
\hline & guri-si & 1994.5 .6 \\
\hline & Namyangju-si & 1995. 1.3 \\
\hline & Osan-si & 1993.1 .5 \\
\hline & siheung-si & 1994. 8.12 \\
\hline & gunpo-si & 1994. 5.4 \\
\hline & Uwang-si & 1994. 8. 2 \\
\hline & Hanam-si & 1993. 5.26 \\
\hline & Yongin-si & 1994. 4. 9 \\
\hline & Paju-si & 1996. 3. 1 \\
\hline & Icheon-si & 1994. 6.17 \\
\hline & Anseong-si & 1994. 3.7 \\
\hline & Gimpo-si & 1998. 4. 1 \\
\hline & Yangju-gun & 1993.8 .6 \\
\hline & Yeoncheon-gun & 1993.12 .27 \\
\hline \multirow{13}{*}{ Gangwon-do } & Gangwon-do & 1994. 6.20 \\
\hline & Chuncheon-si & 1995. 4.22 \\
\hline & Wonju-si & 1995. 2.15 \\
\hline & Gangneung-si & 1995. 1.19 \\
\hline & Donghae-si & 1994.11.18 \\
\hline & Taebaek-si & 1994. 5.23 \\
\hline & Sokcho-si & 1993.11 .30 \\
\hline & Samcheok-si & 1995.1 .7 \\
\hline & Hongcheon-gun & 1994.12 .24 \\
\hline & Hoengseong-gun & 1993.11.24 \\
\hline & Yeongwol-gun & 1994.12 .7 \\
\hline & Pyeongchang-gun & 1995. 1.10 \\
\hline & Jeongseon-gun & 1994.12. 1 \\
\hline
\end{tabular}




\begin{tabular}{|c|c|c|}
\hline Regional governments & Local governments & Time of Adoption \\
\hline \multirow{6}{*}{ Gangwon-do } & Cheolwon-gun & 1993.1 .11 \\
\hline & Hwacheon-gun & 1994. 5.19 \\
\hline & Yanggu-gun & 1995.6 .9 \\
\hline & Inje-gun & 1994.10 .30 \\
\hline & Goseong-gun & 1994.10 .26 \\
\hline & Yangyang-gun & 1996.11.18 \\
\hline \multirow{4}{*}{ Chungcheongbuk-do } & Chungcheongbuk-do & 1998.2 .6 \\
\hline & Cheongju-si & 1992. 1.4 \\
\hline & Okcheon-gun & 1992.9 .5 \\
\hline & Eumgseong-gun & 1998.12 .1 \\
\hline \multirow{16}{*}{ Chungcheongnam-do } & Chungcheongnam-do & 1994. 5.24 \\
\hline & Cheonan-si & 1995.5 .10 \\
\hline & Gongju-si & 1994.8 .10 \\
\hline & Boryeong-si & 1995. 1.15 \\
\hline & Asan-si & 1995. 1.1 \\
\hline & Seosan-si & 1995.3 .8 \\
\hline & Nonsan-si & 1994. 9.12 \\
\hline & Geumsan-gun & 1994.9 .2 \\
\hline & Yeongi-gun & 1994.10 .4 \\
\hline & Buyeo-gun & 1994. 8.10 \\
\hline & Seocheon-gun & 1994. 7.25 \\
\hline & Cheongyang-gun & 1994.8 .5 \\
\hline & Hongseong-gun & 1994.8 .16 \\
\hline & Yesan-gun & 1994. 7.30 \\
\hline & Taean-gun & 1994. 4.11 \\
\hline & Dangjin-gun & 1994.8 .1 \\
\hline \multirow{14}{*}{ Jeollabuk-do } & Jeollabuk do & 1992.12 .7 \\
\hline & Jeonju-si & 1998.1 .7 \\
\hline & Gunsan-si & 1995. 1.13 \\
\hline & Ilksan-si & 1995. 5.9 \\
\hline & Jeongeup-si & 1995.1 .13 \\
\hline & Namwon-si & 1995. 1.12 \\
\hline & Kimje-si & 1995. 2.4 \\
\hline & Wanju-gun & 1992.10 .14 \\
\hline & Jinan-gun & 1994. 7.30 \\
\hline & Muju-gun & 1992.10 .8 \\
\hline & Jangsu-gun & 1993. 6.16 \\
\hline & Imsil-gun & 1993.12 .31 \\
\hline & Sunchang-gun & 1994.11 .29 \\
\hline & Gochang-gun & 1992. 8.10 \\
\hline \multirow{4}{*}{ Jeollanam-do } & Jeollanam-do & 1992.10 .19 \\
\hline & Mokpo-si & 1993. 5.17 \\
\hline & Yeosu-si & 1993.8 .9 \\
\hline & Suncheon-si & 1995. 1.10 \\
\hline
\end{tabular}




\begin{tabular}{|c|c|c|}
\hline Regional governments & Local governments & Time of Adoption \\
\hline Jeollanam-do & $\begin{array}{c}\text { Naju-si } \\
\text { Gwangyang-si } \\
\text { Damyang-gun } \\
\text { Gokseong-gun } \\
\text { gurye-gun } \\
\text { Goheung-gun } \\
\text { Boseong-gun } \\
\text { Hwasun-gun } \\
\text { Jangheung-gun } \\
\text { Gangjin-gun } \\
\text { Haenam-gun } \\
\text { Yeongam-gun } \\
\text { Muan-gun } \\
\text { Hampyeong-gun } \\
\text { Yeonggwang-gun } \\
\text { Jangseong-gun } \\
\text { Wando-gun } \\
\text { Jindo-gun } \\
\text { sinan-gun } \\
\end{array}$ & $\begin{array}{l}1995.1 .5 \\
1995.1 .4 \\
1993.6 .9 \\
1993.1 .9 \\
1994.1 .15 \\
1994.4 .12 \\
1994.10 .6 \\
1994.9 .14 \\
1993.10 .5 \\
1993.3 .26 \\
1998.6 .1 \\
1992.10 .2 \\
1994.4 .18 \\
1998.9 .4 \\
1992.10 .13 \\
1994.9 .16 \\
1992.11 .3 \\
1993.9 .22 \\
1994.1 .13 \\
\end{array}$ \\
\hline Gyeongsangbuk-do & Andong-si & 1998. 5.19 \\
\hline Gyeongsangnam-do & $\begin{array}{c}\text { Gyeongsangnam-do } \\
\text { Changwon-si } \\
\text { Masan-si } \\
\text { Jinju-si } \\
\text { Jinhae-si } \\
\text { Tongyeong-si } \\
\text { Sacheon-si } \\
\text { Gimhae-si } \\
\text { Miryang-si } \\
\text { Geoje-si } \\
\text { Yangsan-si } \\
\text { Uiryeong-gun } \\
\text { Haman-gun } \\
\text { Changneong-gun } \\
\text { Goseong-gun } \\
\text { Namhae-gun } \\
\text { Hadong-gun } \\
\text { Sancheong-gun } \\
\text { Geochang-gun } \\
\text { Hapcheon-gun } \\
\end{array}$ & $\begin{array}{l}1992.11 .23 \\
1995.1 .13 \\
1995.1 .9 \\
1995.1 .20 \\
1994.8 .24 \\
1995.1 .20 \\
1995.6 .1 \\
1995.5 .15 \\
1995.1 .14 \\
1995.1 .14 \\
1994.4 .14 \\
1992.7 .30 \\
1994.5 .31 \\
1993.8 .23 \\
1993.7 .20 \\
1992.8 .24 \\
1992.9 .15 \\
1992.9 .15 \\
1995.12 .9 \\
1997.12 .25 \\
\end{array}$ \\
\hline Jeju-do & Seogwipo-si & 1993. 9.22 \\
\hline
\end{tabular}

